\title{
Properties and usage of Liquidambar orientalis
}

\author{
Ayten Gizem Özbek and Seda Ersus Bilek* \\ Food Engineering Department, Ege University, Turkey
}

\begin{abstract}
Liquidambar orientalis, as an endemic species, has been serving many crucial benefits to human. Especially medicine and cosmetic industry have been taking advantage of this advantageous tree. However, lack of knowledge and researches about this plant causes us to miss a valuable molecules and composition for health and nutritional products. Therefore, in this article, our aim is to give a brief information about Liquidambar orientalis and its usage.
\end{abstract}

\section{Introduction}

\section{Phenolic compounds}

Antioxidants are described as the compounds that can create a defense mechanism against free radicals, though their concentrations are low [1]. Antioxidants have the ability to capture reactive oxygen species (ROS) [2]. Antioxidants are found in plant materials and supplies from plant materials [3] and most of the antioxidant resources rely on plant phenolics [4]. Plant phenolics are synthesized during normal growth of plants as secondary metabolites [5].

Phenolics have antioxidant, anticarcinogenic, antimutagenic and antimicrobial effects through their chemical structure [6]. This feature opens a wide range of usage area to the plants with high phenolic compound levels. There are a lot of researches that a diet with rich antioxidant content may provide various of chronic diseases [7]. Oxidative damage of DNA, proteins and lipids can trigger cardiovascular diseases, cancer and many other problems [8]. Therefore, it is considered that dietary antioxidants may provide protection against oxidative diseases [9].

\section{Phenolic extraction}

A various number of plant species has been used for ages with a great number of purposes. In a wide range of plant parts as leaves, flowers, heartwood and balsam that shows high phenolic content were used for phenolic extraction through the years. The diversity of total phenolic compound studies obtains a huge variety of plant species: Dandelion (Taraxacum officinale), English Lavender (Lavandula angustifolia), Mexican orageno (Poliomintha longiflora), society garlic (Tulbaghia violacea) [3], berries [10], quince (Cydonia vulgaris) [11], carrot (Daucus carota L.) [12]. One of this precious plant is Liquidamdar orientalis (L. orientalis), in another name, Anatolian Sweet Gum tree. L. orientalis trees can be mostly distributed in the United States of America, Turkey and China.

\section{Features of liquidambar orientalis}

\section{Distrubition of Liquidamdar species}

Phenolic-rich plant L. orientalis is usually known as Sığla, günlük or amber ağacı (amber tree) in Turkey and it belongs to order of Hamamelidales, family Hamamelidaceae. Name of L. orientalis comes from Latin and Arabic origin. It is a compose of liquidius (in Latin) and amber (in Arabic) which refers to "odoriferous liquid" [13].

Length of $L$. orientalis trees can be classified as medium to tall. The tallest Liquidambar tree was recorded in Sütçüler, Turkey, with $35 \mathrm{~m}$. L. orientalis is monoecious [14]. Fruit does not always leave the tree. It can stay for one year from its production [15].

Liquidambar species are distributed only in North America, Southern West part of Turkey and East Asia [16]. The endemic L. oritantalis species are only found in the southern west of Turkey, in Marmaris, Köyceğiz, Çine, Bucak and Antalya [17]. L. orientalis and philogenetically close other species Liquidambar styraciflua (North America) and Liquidambar formosana (East China and Formosa Island) which have enormous economic and ecologic impact [18]. Only four Liquidambar species could survive and show distribution today worldwide: Liquidambar orientalis L. (L. orientalis), Liquidambar formosana (L. formosana), Liquidambar styraciflua L. (L. styraciflua), and Liquidambar acalycina (L. acalycina) [19].

\section{Origin and history of Liquidamdar orientalis}

Ancestors of Liquidambar species has been identified by paleonthology and distribution of this species on earlier geological times (including Cretaceous, Eocene, Oligocene, Miocene, Pliocene and Pleistocene) were in North America and Euroasia. After a Glacial period, distribution showed similar properties with today [14].

Patients with other pituitary hormone deficiency were treated accordingly with hormone replacement to attain normal hormone levels before starting $\mathrm{rGH}$.

L. orientalis has always been there for human health. This plant has been used for the treatment of skin diseases like fungi, scabies; gastric problems; asthma and bronchitis. Local people have understood the importance of this tree dating back to the sixth and seventh centuries.

${ }^{\star}$ Correspondence to: Seda Ersus Bilek, Food Engineering Department, Ege University, Turkey, E-mail: seda.ersus@ege.edu.tr

Key words: Liquidambar orientalis, plant phenolics, novel food ingredient

Received: October 22, 2018; Accepted: November 12, 2018; Published: November 19, 2018 
It is claimed that Greek physicians used liquid storax just as Arabician physicians [20] before it has been used as medicine and cosmetic industry [21]. Moreover, "Ala'im-i Cerrahi" (the book of medicine from early 16th century) claims that oil of Liquidambar species can be used as medicine. Dermatological problems, lung diseases, stomachache and so on are tried to be healed by using cultural therapy systems by using Liqudambar oil for many years in Anatolia [22].

\section{Chemical composition of Liquidamdar orientalis}

One of the properties of Siğla tree gives a rise to a new area as functional food: phenolic components. Protocatechuic acid, (-)-epicatechin and gallic acid were determined as the major phenolics in sığla leaves [23]. Other phenolic compounds and their concentrations that obtained by ethanolic extract can be found in Table 1. By usage of these natural phenolic compounds, it can be effective to produce novel antioxidant food products with an aromatic odour.

Essential oil (Sığla Oil) and eight other species were determined for their antioxidant properties [24]. In that study, they characterized 66 components from Sığla oil. The major components were menthol, 17b-dihydroxy-5b-androstan-3one and octyl alcohol acetate. Siğla oil had the most valuable results in both screening methods [24].

Sığla oil contains a huge number of cinnamic acid which has a great impact as antimicrobial and antioxidant properties. Thus, antimicrobial properties of this tree can be obtained [19]. In addition to oil, the leaves of the Liquidambar trees have antimicrobial properties. Terpinen4-ol, a-terpineol, $\alpha$-pinene, and sabinene from leaf oil have the most important chemicals for providing antibacterial feature [19].

\section{Industrial usage of Liquidamdar orientalis}

Medical and cosmetic properties of this plant have been known for a long time and it is mostly used in the southern west part of Turkey [23]. Usage of Sığla oil known as a fixative in soaps and perfumery. Medical properties are based on Sığla oil (as known as storax or styrax) and essential oils from an extract of leaves [14].

Swine influenza virus $\mathrm{H} 1 \mathrm{~N} 1$ is susceptible to the antiviral drug Tamiflu ${ }^{\star}$ which has an ingredient "oseltamivir phosphate". Oseltamivir phosphate synthesis from shikimic acid and Chinese star anise plant was the initial source for shikimic acid before Escherichia coli's production. Still, some of the plant species are used for shikimic acid production. Liquidambar species, specifically L. styraciflua, contains shikimic acid in their leaves, bark, and young seeds. Therefore, Liquidambar species are valuable resources for that effectively inhibit the H1N1 virus. [19].

Table 1. Compounds of phenolics in the ethanolic extract of the leaves of $L$. orientalis var. orientalis [23]

\begin{tabular}{|c|c|}
\hline Phenolic compound & Concentrations (mg/g extract) \\
\hline Gallic acid & $3.258 \pm 0.035$ \\
\hline Protocatechuic acid & $12.232 \pm 0.118$ \\
\hline (+)-Catechin & $1.622 \pm 0.007$ \\
\hline Chlorogenic acid & $0.429 \pm 0.017$ \\
\hline Caffeic acid & $1.265 \pm 0.027$ \\
\hline (-)-Epicatechin & $7.954 \pm 0.493$ \\
\hline p-Coumaric acid & $0.295 \pm 0.003$ \\
\hline Ferulic acid & $0.811 \pm 0.031$ \\
\hline Quercetin & $0.17 \pm 0.005$ \\
\hline Kaempferol & $0.031 \pm 0.0003$ \\
\hline Kaempferol & 0.006 \\
\hline
\end{tabular}

\section{New aspects and researches for Liquidamdar orientalis}

Antibacterial properties [17] and antioxidant activity [24] of the balsam of this tree "Sığla yağı" or "Sığla oil" has been identified with in vitro experiments. Antioxidative activity of Sığla oil in the rat livers, that has been treated with hepatotoxic and oxidative stress, was proofed by Suzek and his colleagues [9]. Results of their experiments were represented the antioxidative and protective effect of Siğla oil on rat livers. Besides these features, nowadays, new researches shows that oil of $L$. orientalis has high antibacterial and antioxidant activities [25]. Bayazit has shown the considerable effect of Siğla oil on healing stroke parameters high concentration of Siğla oil's facilitator effect on the breakdown of fibrin bloot clots and decreased systolic and diastolic pressure [26]. In addition to these studies, Siğla Oil has a high antibacterial feature on mainly B. cereus and the other bacteries ( $B$. subtilis, C. xerosis, E. aerogenes, E. faecalis, K. pneumoniae, M. luteus, $M$. smegmatis, P. vulgaris, P. aeruginosa, P. fluorescens and S. aureus) [17].

Essential oils from L. Orientalis resin has also nematicidal activity against Bursaphelenchus xylophilus (common pine wood nematode). Major components of this extract were determined as hydrocinnamyl alcohol (41\%) and trans-cinnamyl alcohol (45\%) by Kim et al. [27].

Prevention from Aedes aegypti (A. aegypti) mosquitoes (causes yellow fever disease) is possible with Sığla oil. The LC50 value was calculated to be $194.93 \mathrm{ppm}$ for this environmentally friendly insecticide [28].

\section{Liquidambar orientalis as a food ingredient}

Plant species always used for developing human health. Herbal therapies and phytotherapy drugs regain their popularity and consumers demand increases for plant-based drugs. Plant based additives or drugs used for protection from free radical attacks on DNA and diseases caused by this attack. Besides their health promoting effects, another opportunity to use phenolics from plant species can decrease the speed of aging, therefore in cosmetic industry, its usage gains importance [29].

\section{Conclusion}

Sığla leaves or sığla oil has not been used as a food additive until now. Of course, before usage possibilities of this compounds in food products, cytotoxicity, impurities, chemical properties when it is added in a specific food, toxicokinetic studies, sub chronic toxicity tests, genotoxicity, chronic toxicity and carcinogenicity tests and so on need to be studied. Due to the experiments, proper dose as a food additive should be determined before it is released. However, the high phenolic concentration of this tree and other medicinal and antibacterial effects of this tree gives us an idea to clear our minds to see new horizons. We believe that the unique features of Liquidambar species are promising for many industrial areas. Hopefully, as long as the number of the studies are increased, novel usage idea for this plant will be discovered.

\section{Acknowledgement}

We thank Gülşen Esen, Selinsswqawq2az Gökçe and Nihal Kurban for their precious support and effort.

\section{References}

1. Mathew S, Abraham TE (2006) In vitro antioxidant activity and scavenging effects of Cinnamomum verum leaf extract assayed by different methodologies. Food Chem Toxicol 44: 198-206. [Crossref]

2. Lone AA, Ganai SA, Ahanger RA, Bhat HA, Bhat TA, et al. (2013) Free radicals and antioxidants: Myths, facts and mysteries. Afr Pure Applied Chem 7: 91-113. 
3. Zheng W, Wang SY (2001) Antioxidant activity and phenolic compounds in selected herbs. J Agric Food Chem 49: 5165-5170. [Crossref]

4. Atoui AK, Mansouri A, Boskou G, Kefalas P (2005) Tea and herbal infusions: their antioxidant activity and phenolic profile. Food Chem 89: 27-36.

5. Dai J, Mumper RJ (2010) Plant phenolics: extraction, analysis and their antioxidant and anticancer properties. Molecules 15: 7313-7352. [Crossref]

6. Działo M, Mierziak J, Korzun U, Preisner M, Szopa J, et al. (2016) The potential of plant phenolics in prevention and therapy of skin disorders. Int J Mol Sci 17: 160. [Crossref]

7. Griel AE, Kris-Etherton PM (2006) Tree nuts and the lipid profile: a review of clinical studies. Br J Nutr 96: S68-S78. [Crossref]

8. Halliwell B (1996) Antioxidants in human health and disease. Annu Rev Nutr 16: 33-50.

9. Suzek H, Celik I, Dogan A, Yildirim S (2016) Protective effect and antioxidant role of sweetgum (Liquidambar orientalis) oil against carbon tetrachloride-induced hepatotoxicity and oxidative stress in rats. Pharm Biol 54: 451-457. [Crossref]

10. Rodriguez-Mateos A, Heiss C, Borges G, Crozier A (2013) Berry (poly) phenols and cardiovascular health. J Agric Food Chem 62: 3842-3851. [Crossref]

11. Fiorentino A, D’Abrosca B, Pacifico S, Mastellone C, Piscopo V, et al. (2008) Isolation and structure elucidation of antioxidant polyphenols from quince (Cydonia vulgaris) peels. J Agric Food Chem 56: 2660-2667. [Crossref]

12. Zhang D, Hamauzu Y (2004) Phenolic compounds and their antioxidant properties in different tissues of carrots (Daucus carota L.). J Food Agric Env 2: 95-100.

13. Önal S, Özer S (1985) Problems in the Production and Evaluation of Sweet Grain Oil in Turkey. Forest Products Industry Congress, Trabzon.

14. Efe A (2000) Liquidambar orientalis Hamamelidaceae Curtis. Botan Mag 17: 66-71.

15. Efe A (1987) Studies on the morphological and palynological characteristics of Liquidambar orientalis Mill. in Turkey. Istanb Univ Orman Fak Derg 37: 84-114.

16. Hoey M., Parks CR (1991) Isozyme divergence between eastern Asian, north American, and Turkish species of Liquidambar (Hamamelidaceae). Am Bota 78: 938-947.

17. Sağdıç O, Özkan, G, Özcan M, Özçelik S (2005) A study on inhibitory effects of sığla tree (Liquidambar orientalis Mill. var. orientalis) storax against several bacteria. Phytother Res 19: 549-551. [Crossref]
18. Günal N (1994) Relief and climate relations in the distribution of Liquidambar orientalis (Anatolian sweetgum tree) in southwest Anatolia. Tur Geog 29.

19. Lingbeck JM, O'Bryan CA, Martin EM, Adams JP, Crandall PG (2015) Sweetgum: An ancient source of beneficial compounds with modern benefits. Pharmacogn Rev 9 : 1-11. [Crossref]

20. Howes FN (1950) Age-old resins of the Mediterranean region and their uses. Econ Bota 4: 307-316.

21. Hafizo glu H (1982) Analytical studies on the balsam of Liquidambar orientalis Mill. by gas chromatography and mass spectrometry. Holzforschung 36: 311-313.

22. Arslan MB, Şahin HT (2016) A Forgotten Forest Product Source: Anatolian Sweetgum Tree (Liquidambar orientalis Miller). J Bartin Fac Forest 18: 103-117.

23. Saraç N, Sen B (2014) Antioxidant, mutagenic, antimutagenic activities, and phenolic compounds of Liquidambar orientalis Mill. var. orientalis. Ind Cro Prod 53: 60-64.

24. Topal U, Sasaki M, Goto M, Otles S (2008) Chemical compositions and antioxidan properties of essential oils from nine species of Turkish plants obtained by supercritical carbon dioxide extraction and steam distillation. Int J Food Sci Nutr 59: 619-634. [Crossref]

25. Gan RY, Xu XR, Song FL, Kuang L, Li HB (2010) Antioxidant activity and total phenolic content of medicinal plants associated with prevention and treatment of cardiovascular and cerebrovascular diseases. J Med Plants Res 4: 2438-2444.

26. Bayazit V (2009) Effects of Sweet Gum \{Liquidambar orientalise Mulberry Leaves (Mortis alba) and the Larval Ganglion Extracts of Silkworm (Bombyx mori) on Stroke Parameters (Hemoglobin, Strokin, Cortexin, Frontalin, Temporalin, Parietalin, Occipitalin, Brain Ventriculin, Hemorrhagic Clot) in Rabbits (Lepus capensis). J Anim Vet Adv 8: 2164-2170.

27. Kim J, Seo SM, Lee SG, Shin SC, Park IK (2008) Nematicidal activity of plant essentia oils and components from coriander (Coriandrum sativum), oriental sweetgum (Liquidambar orientalis), and valerian (Valeriana wallichii) essential oils agains pine wood nematode (Bursaphelenchus xylophilus) J Agric Food Chem 56:7316-20. [Crossref]

28. Imam H, Riaz Z, Sofi G (2013) Mosquito larvicidal efficacy of storax (Liquidambar orientalis) against Aedes aegypti L. larvae. J Nat Remedies 13:104-108.

29. Ghazali AR, Abdullah R, Ramli N, Rajab NF, Ahmad-Kamal MS, et al. (2011) Mutagenic and antimutagenic activities of Mitragyna speciosa Korth extract using Ames test. J Med Plants Res 5: 1345-1348. [Crossref]

Copyright: (C2018 Özbek AG. This is an open-access article distributed under the terms of the Creative Commons Attribution License, which permits unrestricted use, distribution, and reproduction in any medium, provided the original author and source are credited. 